\title{
Corruption in the Land Question and Protracted Conflict in Bungoma County, Kenya 1992-2019
}

\author{
Cherotwei G Simotwo ${ }^{1}$ Xavier F Ichani ${ }^{2}$ \\ 1. MA Student, School of Security, Diplomacy and Peace Studies, Kenyatta University \\ 2. Lecturer, Department of International Relations, Conflict and Strategic Studies, Kenyatta University
}

\begin{abstract}
Corruption is argued to be persistent and enduring matter of global concern. This article investigated corruption in the land question and protracted conflict in Bungoma County, Kenya 1992-2019. Corruption is defined in the form of bribery, land grabbing and privatization of public land. This study explored the dynamics of corruption and its influences on land distribution. It also examines how corruption is used in galvanizing intra-ethnic differentiation leading to protracted conflict on historical land injustice. Moreover, the study seeks to demonstrate how corruption has watered down peacebuilding initiatives in the aftermath of land-based conflict in Mount Elgon, Kenya. The study was anchored on a combination of greed versus grievance theoretical framework together with the theory of ethnic mobilization. The greed and grievance theory defines the problem of land grabbing as self-enrichment while ethnic mobilization theory explained the process by which political elites galvanize intra-ethnic differentiation leading to conflict between Soy and Mosop clans. The study used a case study design to describe the characteristics and dynamics of corruption and its relation to land allocation and mobilization of members of the community into armed violence. The target population included residents of Mount Elgon constituency, politicians, members of the National Government Administrative Officers (NGAO), County government officials and the civil society. Primary data was obtained from a non-partisan and gender sensitive samples of one hundred and thirty-seven respondents and twenty-four key informants. The study found out that endemic corruption weaved with politics was a major hindrance to fair and transparent land allocation in the region. Moreover, women especially the widows and low income earners were the most disadvantaged in the process of land allocation. The study recommends an independent audit of the land dispensation to allow issuance to the deserving individuals.
\end{abstract}

Key Words: Corruption, Protracted Land Conflict, Bungoma County, Chepyuk settlement scheme, Sabaot

DOI: $10.7176 / \mathrm{IAGS} / 91-05$

Publication date:September 30th 2021

\section{Introduction}

Corruption and resource distribution remains a matter of global concern. In Africa, corruption is arguably persistent in the management of land resource and endemic in the Ministry of Lands. Due to industries disarticulation, many economies in Africa are agrarian and dependent on land as source of livelihood. This makes land an emotive factor of production and likely cause of conflict in the study area. This region witnessed land related conflict since 1992 pitting all the ethnic groups domiciled in the County. The epicenter of the conflict was in the Chepyuk settlement Scheme hived from Mount Elgon Forest in 1971. The scheme is still government forest and yet to be gazetted as farmlands. Gazetting of the scheme has severally been tabled to parliament by both the Ministry of Lands and Environment for deliberations. The consequence of the corrupt land distribution has had grave national and regional security. Because of corruption many cases of ethnic conflict were witnessed causing human sufferings through killings, displacement and internally displaced communities and refugees across international borders.

This state of affairs underscores the greed among those in leadership who use their position to expropriate public lands particularly forest land and distribute to their cronies and themselves. It also defines the grievance from those among the communities in the area who felt they were deprived what is rightfully theirs. The problem further exemplifies the ethnic mobilization that follows the quest and competition for the land resource.

\section{Objectives of the Study}

The main objective of this study was to interrogate the relationship between corruption and protracted land-based conflict in Bungoma County $(1992-2019)$. The research project sought to explore the following specific objectives: 
1. To ascertain the perspectives of the members of the Sabaot community in regards to the nexus between corruption and protracted land dispute in Bungoma County, 1992-2019.

2. To explore how corruption influences the process of land allocation and distribution in Bungoma County, 1992-2019.

3. To examine how political corruption has interfered with the peacebuilding initiatives in the protracted land-based conflict in Bungoma County, 1992-2019.

\section{Research Questions}

This research aimed at answering the following questions:

3.1 What are the community perspectives on the nexus between corruption and protracted land dispute in Bungoma County, 1992-2019?

3.2 How has corruption influenced the process of land allocation and distribution in Bungoma County, 1992-2019?

3.3 In what ways has corruption inhibited the peacebuilding initiatives to resolve the protracted landbased conflict in Bungoma County, 1992-2019?

\section{Methodology}

The study used both qualitative and quantitative method ideal for case studies and descriptive surveys Kothari (2003) Kothari (2011), Nachmias and Nachmias, (1996). With case study design, the researcher studied the rife corruption in the land question from 1992 to 2019. This period was chosen because case studies require long period of time to undertake. As such the study focused a period of three decades. Descriptive survey was insightful in describing momentous events so as to ensure achievement of in-depth analysis. The themes described include perception of community on the land question, the nexus between corruption and land allocation as well as the effect of corruption on peacebuilding activities in the region. Exploratory and descriptive methods helped to reveal the corrupt deals and tendencies undertaken under cover of darkness because of the shame associated with it. Although qualitative approach is widely used in the study, the use of basic quantitative evidence was purposive to augment qualitative analysis.

The study was undertaken in Bungoma County with Mount Elgon constituency as the unit of analysis. Mt Elgon Constituency has two Deputy County Commissioners heading two sub Counties of Cheptais and Mt Elgon for the purpose of National Government Coordination. As far as County Government is concern, it is one Sub County (Mt Elgon Sub County) with six Wards.

The study area is located on the south eastern slopes of Mount Elgon. It has a population of approximately 172,379 people. The Sub-County occupies an area of $944 \mathrm{~km}^{2}$. Even though Kapsokwony is the sub-County headquarters, Cheptais town is the economic heart of the Sub- County. It is also the gateway to Chwele, the largest open-air market in Bungoma County. The area is predominantly occupied by four Sabaot clans: the Bok, Someek, Koony and the Mosopisyeek (also called the Ogiek/Ndorobo). The Bok, Someek and Koony settled on the lower slopes and are cumulatively called Soy. They are mainly agro-pastoralists and make up 80 percent of the Sabaot, while the Ogiek/Ndorobo sometimes called Mosop, who are mainly hunters and gatherers, account for the remaining 20 percent. Other communities living in Mount Elgon Sub-county are the Bukusu and the Iteso. Though relative peace prevailed after the intervention by the military, the community and the government are yet to resolve the root cause of the conflict and finalize the process of land allocation due to corruption in the land distribution.

\section{Literature Review}

A lot of literature on corruption is abound. Land corruption in particular remains emotive and needs immediate attention. Corruption and the land problem in Mount Elgon can be traced to 1971. The process was marred with corruption leading to discontent and violence which broke out in 2006 . The violence spread in the whole County pitting the Sabaot and the Ogiek/ndorobo over a strongly contested land adjudication programme that had dragged over four decades. 
Transparency International argues that where land governance is inefficient, corruption levels are often high (Transparency International, 2011).In general, the sleaze remains monumental in the global South compared to the global North. For, Central America, Ruhl (2011) contends that corruption is widespread and reported daily on newspapers. He argues that corruption transverses from Panama to Guatemala where there are regular reports on bribery and embezzlement scandals involving senior public officials.

With globalization, new trend complicates land governance structure and the existing corruption in the land sector (Saturnino M. Borras Jr., et al, 2011). The scramble for land by the multinational has been equated to new colonialization although without force but through corruption. Though multinational corporations are not involved in the context of Bungoma County, the jostling an interest of different groupings on the land allocation can be likened to scramble to resource.

Rose-Ackerman, Susan and Plifka (2016) argues that corruption pervades all spheres of life. Corruption can be categorized as bribery, extortion, and exchange of favours, nepotism, cronyism, judicial fraud, accounting fraud, electoral fraud as major forms of corruption Rose-Ackerman, \& Bonnie (2016). Political sycophants of influential powerful politicians have also been allocated land (Ndungu Land Report, 2004). Some of these sycophants are well known in the region.

Margit (2010) delves into the moral component of the individuals arguing that it is a phenomenon that involves personal commitment. Blundo et al (2006) presents a gloomy picture for Africa in as far as corruption is concerned. Kibwana, Wanjala, and Owiti, (1996) identify various dimensions of corruptions to include political corruption, sociological and economic corruption in land registries and procurement. Transparency international corruption perception index (CPI) 2019 ranks Kenya at number 137 out of 198 of the most corrupt countries. On the state of corruption in Africa, Hope (2000) contends that, so pervasive is the phenomenon of corruption in the region that it has been labelled the 'AIDS' of democracy which is destroying the future and fundamental fabric of many societies. Boone (2012) highlights the role corruption play in determining who gets what in regard to land distribution.

What in Kenya is usually called the "land question" has been dominated by the inequalities of white settler land confiscation, Robert (2012). By 1914 nearly five million acres of land had been transferred, and by independence in 1963 over seven million acres. Kenya's land governance system therefore from the onset was never meant to be inclusionary and equitable according to Klopp \& Odenda (2017). Chepyuk land scheme was hived from Mount Elgon Forest for settlement. The State being the custodian of these lands used their position to dish out to cronies through the Lands officers, Provincial Administration and Members of Parliament. The allocation is claimed to have been corruptly managed and the process went out of control leading to the conflict. No politician was ready to listen to the complaints of those who protested or questioned.

Anassi (2004) points at how corruption permeated the land system in Kenya from colonial to post-colonial period. Owing to the fact that corruption in land matters is at the very core of insecurity and conflict, Kenya is still struggling with the problem of corruption in land registries. Corruption on the land question in Mount Elgon is monumental in terms of proliferating conflict and by extension security. It is against this backdrop that the intended study delved into the implications of corruption in the land question and protracted conflict (19922019) with a view to recommendation of possible solution. Note that the land question is still pending in Parliament and the people of Mount Elgon will have to wait a little longer before Chepyuk land issue is resolved. This state of limbo creates a state of uneasiness among the population creating tension and state of negative peace.

\section{Theoretical Framework}

There are several theories that can be used to describe, explain, predict and prescribe appropriate contents of corruption in land resource distribution and conflict in Bungoma County. The most relevant theories chosen for this study were grievance versus greed theory as was postulated by Paul Collier and Anke Hoeffler (2000) and the Ethnic Mobilization Theory as advanced by Peter Vermeersch, (2012). The two have been chosen because of their analytical tools in explaining corruption and societal relations. The two theories supplemented each other to explain the existing nexus between Corruption, land distribution and protracted conflict in Bungoma County. Undoubtedly, the two frameworks explain the interrelationships between and among the three variables. While Corruption reinforces biased land distribution and creating ethnic hostility, conflict is often times spurred by greed and grievances leading to protracted conflict. 
While it is true that scholars like Romborah (2008) and Wachira, Muluka \& Wepundi, (2010) have recognized that the conflict in Mount Elgon was largely out of competition for the dwindling resources, it is also the contention of this study that quite in a higher view, the greed and the ensuing corruption in the distribution and allocation of land played a critical role in the protracted conflict. Karuti Kanyinga et al (2008) further reinforce by painting a picture of raw corruption and land grabbing menace by those in leadership.

The study's second theory is ethnic mobilization (Wolff 2007), Rogers Brubaker and David Laitin (1998), (Habyarimana 2008). The theory of ethnic mobilization can be distinguished in four different theoretical perspectives Vermeersch, (2012), Fearon (2004), Michael Hechter (1975) which uses economic viewpoint to argue that the primary cause of ethnic mobilization lies in the nexus of ethnic union and relative deprivation, Langer, (2005), Barth, (1994).Ethnic solidarity according to Olzak (1983) is the conscious identification with a certain ethnic populace and embraces strong ethnic collaboration systems and organizations. The study therefore conceptualised that in Mount Elgon protracted land conflict is depended on corruption, ethnicity and politics.

\section{History of Corruption in the Land Question and Protracted Conflict in Bungoma County}

Kenya's land history is dotted with mischiefs, greed and corruption. The land policy it is argued have revolved around debates on whose rights are to be recognized by the State. The subject on corruption and land matters continue to raise fundamental question of the legitimacy of past land allocations. In many political and electoral cycles, the matter of land and corruption has been argued as emotive and hot potato. Many scholars on land and conflict have concentrated on scarcity leaving the problem of corruption and biasness undiscussed. Corruption is an eclectic term and intangible; it is also shameful and hence difficult to concretise.

The genesis of land conflict in Bungoma County can be traced back colonial period when the Ogiek/Ndorobos were allocated land for crop farming down slopes from their native land holding at Chepkitale up the Moreland of Mount Elgon. (Land Ordinance No. XXVIII of 1938). It is argued that the then British District Commissioner, one Mr. Clay, discussed this proposal with the Ogiek community. The Ogiek refused as they wanted to continue with sheep and cattle keeping up the Mountain. The programme was thus shelved. After Kenya's independence the new independence leadership actualized plan by moving the Ogieke community to Chepyuk settlement scheme in 1971.

The relocation of the Ogiek to Chepyuk settlement scheme did not augur well with the Soy community already living in the scheme. Soon a land conflict pitting the two Sabaot clans (Soy) versus the Ogiek (mosop) erupted. The bone of contestation was that the pastoral Ogiek had been moved from their ancestral lands of Chepkitale to Chepyuk bringing in competition over agricultural land in the scheme. This resonates with what Kanogo (1987) indicated about the settlers' alienation of local lands in the white highlands of Central Kenya. This situation led to conflict between the colonialists and locals in Central Kenya creating the squatter phenomenon in Kenya. This action had ripple effects in the Rift valley including Mount Elgon region of Trans Nzoia.

Even then, the settlement process is argued to have been marred with corruption leading to protests. Cases of underhand dealings by the District Commissioners and District Officers was rampant. Police and civil servants who had no idea of where Chepyuk settlement is were allocated lands dispossessing the deserving cases. In trying to resolve the matter, memoranda to the national government were made albeit with no success (Proceedings of TJRC Report 2011). The bureaucracy at the Kenya's Ministry of Lands could not allow a smooth and transparent land allocation to be implemented.

This dissatisfaction continued until 1989 when the government interceded. The idea was to correct the disorganized Chepyuk Settlement scheme. Mr Francis Lekolool the Provincial Commissioner Western Province at that time is said to have been concerned about the inequitable distribution of the lands and wanted to address but was deployed to other station.

According to Human Rights Watch, (2008), the transfer of Mr Lekolool gave way to the process of land distribution being handled by the District Commissioners and District Officers. These Officers are accused to have corruptly sold the land to underserving individuals. The entire exercise of land allocation was therefore skewed as a result of corrupt officials. Both the first and second phases of Chepyuk Settlement Scheme are said to have been seriously corrupted. Many people, especially several former local politicians and leaders ended up with more than two plots of land than others leaving the deserving cases.

Local Non-Governmental Organization claim that there were two people being allocated one plot. This led to conflict after the land surveyors not cross checking their records or intentionally doing it for kickbacks. Cases of 
same person having several plots using same name or presenting their names in different constructs are also reported. Also, children of school-going age were allocated land using the identity numbers of other people or the dead are reported.

Because of poor land management and alleged corruption, it sowed the first seeds of what has contributed to the land conflict. In the first instance, it is argued that the initiative showed signs of insincerity on the part of local leaders behind the initiative. Romborah (2008), Muluka, Wepundi, Wabira, (2012) have pointed that the relocation of Ndorobo from Chepkitale to Chepyuk scheme created heated debate among the Ndorobo themselves. Consequently, Daniel Moss who was then the Member of Parliament had his way and the Ndorobo community was ultimately moved to Chepyuk in 1971.

According to Wachira, Muluka, Wepundi, (2010) it is the member of parliament of Mount Elgon that asked for this land for own hidden political and economic agenda. The quest for land was initiated by the then Member of Parliament, the late Daniel Moss. In asking for the land from Mzee Kenyatta, Moss said that there was need to move the /Ndorobo to more hospitable and agrarian land. Politically, the Kony/Sabaot leaders it is argued had made mathematics and wanted to increase the number of voters in Chepyuk which happens in an area called Chelebei which is dominated by Bukusu and Iteso communities.

Lynch (2011) associated inter-and intra-communal violence in Mount Elgon on ethnic identity, political competition and underdevelopment. Bone (2012) explores the question of land and politics and in particular indigenous lands versus White settlers' land rights during colonial period. He identifies the settler matter as one dimension of this struggle over the distribution of land. Simmons (2004) underscores the place of political corruption in catalyzing protracted conflict. Latest in this question is the submission of the agenda to Kenya's Parliament to allow for excision of part of the Mount Elgon Forest to allow settlement and the political power play that goes with it. Anassi (2004) asserts that the largest number of cases in Kenyan courts are land cases, where the Land Boards, Surveyors, Politicians contributed substantively.

Palaniswamy \& Krishnan (2012) argues that the power of the dominant distorts resource distribution especially when they are corrupt. Heidenheimer (1970) avers that public office-centered definitions of corruption revolve around the violation of the public trust placed in the official. Manji (2012 avers that a Commission of Inquiry to look into the whole question of land corruption in Kenya was established which exposed how public lands including forests were dished out to those in power.

Africa Centre for Open Governance (Africog) 2009 in their June Report argued that the implementation of the Ndung'u Land Commission report remained largely unimplemented and corrupt dealings in public land continue. Lynch (2006) demonstrates the role of politics in Land distribution in Kenya. Using the Sengwer community case in Trans-Nzoia, Lynch argues that by the end of 1996, most of the plots had been allocated, but not to Sengwer but to civil servants and politicians. Tracing the history of land allocation and distribution during and after independence, Medard (2010), argues that land ownership in the white highlands was partially transferred to Africans after independence, with only marginal measures of broader land redistribution to deter claims coming from squatters.

The nexus between corruption and land control has been widely discussed in Kenya. This phenomenon extended to post Independence Kenya with the issue of land ownership emerging as a major source of disquiet because most armed violence in Kenya is associated with land conflict. It is argued that generally corruption is leading in depriving the poor of their lands.

Working Group (2014) paints a grave picture of how government officials manipulate the governance structures for personal gains. That the systems of governance are weaved like a web of networks for the purpose of extortions and self-aggrandisement thereby creating disillusionments and creating tension and fuel conflicts.

Romborah (2008) views the Mount Elgon conflict from the land scarcity perspective of resources accessibility theory, which considers competition between groups for access and control over limited resources as an important motivating factor for the conflict. However political power play and corruption in the whole setting needs to be debunked.

Olarinmoye (2008) underscores the role of corruption and politics in shaping and determining the future of any state and the control of resources particularly land. Rosser (2006) delved on matters political corruption and theorized that scholars should be asking what political and social factors enable some resource abundant countries to utilize their natural resources to promote development and prevent other resource abundant countries 
from doing the same. In this regard, Rosser was asking the nexus between politics and resource distribution and by extension allocation.

Inge (2019) avers that corruption is an interrelated process that often destroys economies and democracies. He advances extractive political corruption where political power-holders are enriching themselves by abusing their hold on power to benefit from public and private resources. This process helps to interrogate the breadth and depth of corruption. One is thus justified to argue that the Mount Elgon politicians may have used the land resource for their enrichment. Such kind of corruption may include bribery, embezzlement, and fraud for the benefit of individual power-holders and for the regime.

To Transparency International (2009) corruption is extremely hard to document and effectively prosecute. National chapters of Transparency International across the globe rank the problem of land and corruption as one of the top three issues that citizens have consulted them on through their advocacy and legal advice centres. Regardless of the form, corruption in land rights of individuals and communities are violated.

With regard to how corruption has influenced the process of land allocation and distribution in Mount Elgon, Muluka, Wepundi, \& Wabira, K (2012) avers that in 1970 the elders were involved in the distribution of Chepyuk Settlement Forest who agreed not to sell. The problem however was that it was not transparent as corruption sored the distribution of land. This delayed until 1989 when it was annulled yet again because of corruption. It dragged on for over fifty years without being concluded. It was claimed rampant and endemic corruption in the process was witnessed. It is alleged that it was the beginning of corruption yet again.

Peace-building initiatives in post-conflict and conflict-prone societies have an equally constructive record in terms of promoting stability Newman, (2011). Indeed, after the Kenya Defence Forces had ensured that the Sabaot Land Defence Forces guns had been silenced, it was significant that post conflict peacebuilding initiatives are undertaken. During post conflict peacebuilding, some actors prefer to focus on meeting human needs while avoiding peacebuilding processes that deal with corruption issues. Other actors' issue like arms trade or ethnic rivalry are overlooked.

Through peacebuilding and reconciliation, it empowers people to improve and come out of the stigma of war (Donais 2014). It has to help develop constructive relationships amongst the contesting parties to the conflict.Peacebuilding is an analytical and strategic framework for promoting sustainable peace in societies engaged in, emerging from or potentially entering violent conflict Bleiker, Christoph, \& Marc Krupanski, (2012).

Waldman (2009) avers that communities that have gone through conflicts tend to require different methods and needs to bring them back to normalcy. This calls for a whole of nation approach by incorporating the civil society, youth, donors and well-wishers for recovery and restructuring to be implemented. This actually requires total transformational programs. Furthermore, areas emerging from war often experience periodic setbacks and sporadic instances of violence. Mount Elgon Sub County particularly Chepyuk suffered cycles of conflicts for example in 1992 and yet again from 2006-2008 where lands were deserted and the militia were left roaming.

To Galtung (1969) peace is the absence of violence where peace is attained when every effort of policy is geared towards the attainment of technical assistance, new forms of education, irrigation, industrialization. Others argue that not all policy instruments were used to help in peacebuilding in Mount Elgon. Webel (2007) identifies weak or fragile peace similar to Galtung's positive peace and weak or fragile peace which is similar to Galtung's Negative peace. It is therefore important that after 2008, and on the silencing of the guns in Mount Elgon, there is need to interrogate the peace building initiatives to date and analyze its sustainability.

According to Mungou, (2018), several peacebuilding initiatives have been attempted by non-state actors in Mount Elgon land conflict which involved state and non-state actors. The attempts encompassed a wide array of activities and processes aimed at guaranteeing harmony and prevention of future violent conflicts. Therefore, both tangible and intangible dimensions drivers of conflict need to be explored. Among the intangible aspects are the perception and feelings about corrupt dealings in the land matters.

Gurkaynak, Dayton and Paffenholz (2009) argued that to address and have concrete peacebuilding initiatives and to avoid missteps, practitioners should always be explicit from the general beliefs they hold about the conflict they are dealing with. They need to identify and explore the underlying causes and assumptions about how these bases of conflict are causally linked. Further, belief about how the root causes can be transformed and belief about programs of intervention. 
According to Unruh (2010) rectifying land rights in war-torn settings are among the most daunting challenges of peacebuilding. This seems to be the case in Mount Elgon since 2008 when the dreaded rag tag Sabaot Land Defence Forces were annihilated courtesy of the Kenya Defence Forces. Not much seemed to have taken place to augment the efforts of the military yet matters of corruption and land are beyond military solutions.

\section{Findings and Discussions}

The data revealed that there is still problem of land ownership in Bungoma County especially Chepyuk settlement Scheme. From the information gathered $87 \%$ of the respondents acknowledged that there is still a problem of the land while $12 \%$ were non-committal and $1 \%$ disagreed. On how they rate the causes of the Conflict, $82.1 \%$ attributed to government failure while $17.9 \%$ did not attribute it to government failure.

As to how corruption influences land allocation and distribution, $76 \%$ acknowledged that they know of someone who paid money before being allocated land while $24 \%$ were not aware. $21 \%$ of those who own land admitted that they paid money, while $79 \%$ did not affirm that they paid any money. On the role of politicians in the distribution of land, $62.5 \%$ affirmed that politicians use land as bait for their selfish interests. $18 \%$ said politicians did their duties diligently without corruptions while $24 \%$ were not sure or did not bother.

On the basis of land allocation, $52 \%$ of the respondents acknowledged that the issuance of land in Bungoma was influenced by the factor of clannism while $20 \%$ attributed it to money (corruption), $12 \%$ of the respondents attributed it to political influence while $18 \%$ said that it was fairly distributed. On the presence of land conflict, $73.2 \%$ affirmed that there is still land conflict in Mount Elgon while, $22.3 \%$ said there is no problem while $4.5 \%$ were not sure.

On the role of corruption in the distribution of the land, 53\% said corruption informed how land was distributed, $25 \%$ said corruption informed the size an individual was allocated while $22 \%$ were not sure of the role of corruption in land distribution.

Regarding the magnitude of corruption in the land distribution, $11 \%$ said corruption was very high, $30 \%$ said it was high, $12 \%$ said it was low while $9 \%$ said it was very low. To this end high is $61 \%$. As to the relationship between corruption in the land management and Conflict in Bungoma County, a whopping $82 \%$ acknowledged that there was a high correlation between corruption in the land management and conflict in the study area. It is apparent that corruption in the dispensation of land in Bungoma was the cause of the conflict.

Concerning the progress of peace building and reconciliation strategies, $55 \%$ said there is good progress in peacebuilding and reconciliation strategies, 7\% said there is low progress, $29 \%$ said the progress is fair while $9 \%$ said there is no progress in peacebuilding and reconciliation strategies. As to the recommendation for lasting peace in the region $4 \%$ said there is need to finalize the land settlement. $43 \%$ said inclusivity and fairness in the distribution of land, $16 \%$ said issuance of title deed will create lasting peace. $4 \%$ said responsible politics is critical for lasting peace; $7 \%$ called for improved socio-economic empowerment, $21 \%$ called for sustained peace promotions while $3 \%$ were not sure. $2 \%$ called for critical consideration of views of Elders and Laibon by peace stakeholders.

From the above data therefore, one is justified to conclude that corruption has been the major inhibitor to peace building as it curtails fairness, transparency and honesty in addressing the skewed/biased distribution of land. Peacebuilding initiatives are therefore interfered with, through political and biased machinations. It is also observed that idiosyncratic beliefs of the Soy and Mosop communities to a large extend played a role in interference of the peace building initiatives. The use of the security forces particularly the military because they were not prone to political interference helped to a great extent in peacebuilding.

\section{Conclusion}

It has been evident that corruption and land conflict is directly proportional. The higher the corruption the more tension it became in the study area. The nexus of corruption and the land conflict was confirmed by the data gathered. The study also made conclusion that one of the biggest reasons why there was conflict in the region was because of corruption in the land distribution.

It was also mentioned by one of the respondents that there have been many commissions formed to address the land question but none was implemented. They mentioned the Peter Kaguthi Commission and the Solomon Ouko Commission. The latest was the Parliamentary Committee on the excision of Mount Elgon Forest which 
was discussed in Parliament and its verdict as at the time of writing this study was yet to be disseminated and acted upon.

It is therefore important for the politicians, government officials to stop corrupt practices while distributing resources particularly land. It is further concluded that there is still animosity and suspicion between the Soy and Mosop ethnic communities. Further, there is contention on the perspectives of the two ethnic groups both on who should be the rightful owner of the land. Further the construction of the ethnicity - Soy and Mosop require further study as the two terms are contentious.

From the study, corruption in the land allocation and distribution was evident. Corruption was orchestrated through skewed and biased allocation and distribution of land. Land remained central to the majority of the respondents as they depend on it for food production and wealth creation. Speedy and fair dispensation of the resource is therefore critical for peace to be realized. Also, the politicians must stop promising the people free land that may not be available.

While population is growing, it is recommended that alternative sources of livelihood perhaps need to be advanced by government in Bungoma County particularly Mount Elgon and other parts of Kenya that have similar problem. Land as factor of production being finite calls for new way of living and be inculcated to the growing population.

It has also been apparent that peacebuilding initiative was largely executed using both hard and soft power. The hard power entailed using the military particularly the Kenya Army in neutralizing the Sabaot Land defence Forces. Soon after the militia groups were neutralized the local peace group especially Faith-Based Organisations came in to build trust among the communities. It was however noted that the other arms of government particularly the National Government Administration did not do as much since the land problem was never resolved.

\section{Recommendations}

There is need for both corrupt government officers and local political individuals to be disqualified from handling the land dispensation in the area.

Second, there is a requirement for the Office of the Ethics and Anti-Corruption Commission together with office of the Director of Public Prosecution to move with speed with a view to investigating the extent of corruption in the distribution of land. Those found culpapbe for commission and omission be prosecuted in courts of law.

Further, there is need for an independent audit of the ownerships of the land to be instituted. This will help in identifying deserving beneficiaries of the lands with a view to offering recommendations on how to dispense off the land allocation.

Finally, the National Land Commission takes charge of the process from the Ministry of Lands and Planning Officers. This is to take out the land officers who were found to be accomplices to the corrupt land deals.

\section{References}

\section{Books}

Anassi Peter, (2004), Corruption in Africa: The Kenyan Experience; Trafford Publishing and Dialnet Communications System Limited Kenya, Canada \& Nairobi

Bjerk, P. (2013). The Allocation of Land as a Historical Discourse of Political Authority in Tanzania. The International Journal of African Historical Studies, 46(2), 255-282. Retrieved April 27, 2021, from http://www.jstor.org/stable/24393388

Bleiker, C \& Krupanski, M. (2012). The Peacebuilding Context. In The Rule of Law and Security Sector Reform: Conceptualising a Complex Relationship (pp. 10-19). London: Ubiquity Press. Retrieved October 31, 2020, from http://www.jstor.org/stable/j.ctv6zdbqh.4 
Blundo Giorgio \& Olivier de Sardan Jean-Pierre with Bako, N. \& Alou M.Tidjani (2006), Everyday Corruption and the State: Citizens \& Public Officials in Africa. Translated by Susan Cox, David Philip \& Zed Books, Cape Town \& London

Boone, C. (2012). Land Conflict and Distributive Politics in Kenya. African Studies Review, 55(1), 75-103. $10.2307 / 41804129$

Bujko, M. Fischer, C., Krieger, T. et al. (2016). How Institutions Shape Land Deals: The Role of Corruption. Homo Oecon 33, 205-217. https://doi.org/10.1007/s41412-016-0021-4

Bullock, J., \& Jenkins, M. (2020). Corruption and marginalisation (Rep.). Transparency International. Retrieved April 27, 2021, from http://www.jstor.org/stable/resrep26767

Chayes, Sarah. (2015), Thieves of State: Why corruption Threatens Global Security, (New York, W.W Norton \& Company Inc)

Collier, P. \& Hoeffler, A. (2000). Greed and Grievance in Civil War. World Bank. Retrieved September 7, 2020, from http://www.jstor.org/stable/resrep02495

Cynthia S. Simmons (2004) The Political Economy of Land Conflict in the Eastern Brazilian Amazon, Annals of the Association of American Geographers, 94:1, 183-206, DOI: 10.1111/j.1467-8306.2004.09401010.x

Donais, T. (2014). Centre for International Governance Innovation. Retrieved October 16, 2020, from http://www.jstor.org/stable/resrep05219

Drisko, J. (2013). Constructivist Research in Social Work. In Fortune A., Reid W., \& Miller R. (Eds.), Qualitative Research in Social Work, Second Edition (pp. 81-106). New York: Columbia University Press. doi:10.7312/fort16138.7

Elmi, Afyare Abdi (2010), Understanding the Somalia Conflagration: Identity, Political Islam and Peacebuilding: Pluto Press \& Pambazuka Press, London \& Oxford

Fukuyama Francis, (2015), Political Order and Political Decay: From the Industrial Revolution to the Globalization of Democracy. Publisher: London, Profile Books Limited

Galtung, J. (1969). Violence, Peace, and Peace Research. Journal of Peace Research, 6(3), 167-191. Retrieved September 9, 2020, from http://www.jstor.org/stable/422690

Graycar A., P T. (2013) Understanding Corruption. In: Understanding and Preventing Corruption. Crime Prevention and Security Management. Palgrave Pivot, London. https://doi.org/10.1057/9781137335098 2

Heidenheimer, A. J. (1970). Political corruption: Readings in comparative analysis. New York: Holt Rinehart and Winston. Accessed online on 18 August 2020

Home, Robert. (2012) "Colonial Township Laws and Urban Governance in Kenya." Journal of African Law 56, no. 2 175-93. Accessed October 10, 2020. http://www.jstor.org/stable/41709959.

Huggins, C., \& Frosina, N. (2017). ICT-driven projects for land governance in Kenya: Disruption and e-government frameworks. GeoJournal, 82(4), 643-663. Retrieved April 27, 2021, from http://www.jstor.org/stable/45117414

Jacqueline M. Klopp \& Odenda Lumumba (2017): Reform and counter-reform in Kenya's land governance, Review of African Political Economy, DOI: 10.1080/03056244.2017.1367919

Kanogo, T. (1987). Squatters and the Roots of Mau Mau, 1905-1963. ATHENS: Ohio University Press. Retrieved October 17, 2020, from http://www.jstor.org/stable/j.ctt1rfsnvd

Kanyinga Karuti, Lumuba Odenda and Sebastian Amanor Kojo (2008), The Struggle for Sustainable Land Management and Democratic Development in Kenya: A history of Greed and Grievances in Kojo Sebastian Amanor and Sam Moyo (Editors) Land \& Sustainable Development in Africa, (London and New York, Zed Books, 2008)

Keen, D. (2012). Greed and grievance in civil war. International Affairs (Royal Institute of International Affairs 1944- ), 88(4), 757-777. Retrieved September 7, 2020, from http://www.jstor.org/stable/23255617 
Kempe, R. H , Sr, (2000). Corruption and Development in Africa, in Ed Kempe Ronald Hope Sr and Bornwell C Chikulo, Corruption and Development in Africa: Lessons from Country Case Studies, New York, Pegrave Publishers

Kivutha K, Wanjala S \& Owiti O (1996), The Anatomy of Corruption in Kenya: Legal, Political and SocioEconomic Perspectives, Claripress, Nairobi

Klopp, J. (2000). Pilfering the Public: The Problem of Land Grabbing in Contemporary Kenya. Africa Today, 47(1), 726. Retrieved April 26, 2021, from http://www.jstor.org/stable/4187305

Kothari C R, (2003), Research Methodology: Methods \&Techniques, $2^{\text {nd }}$ Edition, Wishwa Prakashan (New Age International (P) Limited Publishers, New Delhi

Lavrakas, P. J. (2008). Encyclopedia of survey research methods (Vols. 1-0). Thousand Oaks, CA: Sage Publications, Inc. doi: 10.4135/9781412963947

Lund, M. (2005). UNDERSTANDING CIVIL WAR: Evidence and Analysis (pp. 231-258, Rep.) (Collier P. \& Sambanis N., Eds.). World Bank. Retrieved September 7, 2020, from http://www.jstor.org/stable/resrep02484.12

Lynch G. (2006). Negotiating Ethnicity: Identity Politics in Contemporary Kenya. Review of African Political Economy, 33(107), 49-65. Retrieved September 8, 2020, from http://www.jstor.org/stable/4007111

Lynch, Gabrielle (2011) The Wars of Who Belongs Where: The Unstable Politics of Autochthony on Kenya's Mt Elgon, Ethnopolitics, 10:3-4, 391-410, DOI: 10.1080/17449057.2011.596671

Manji, A. (2012). The grabbed state: Lawyers, politics and public land in Kenya. The Journal of Modern African Studies, 50(3), 467-492. Retrieved October 17, 2020, from http://www.jstor.org/stable/41653718

McMullan, M. (1961). A Theory of Corruption. The Sociological Review, 9(2), 181-201. https://doi.org/10.1111/j.1467-954X.1961.tb01093.x accessed on 15 August 2020

Mugenda, Abel Gitau (2011), Social Science Research: Theory and Principles, Applied Research and Training Services (ARTS), Nairobi

Mugenda, Olive M \& Mugenda Abel G (2003), Research Methods: Quantitative and Qualitative Approaches, African Centre for Technology Studies (ACTS), Nairobi

Nachmias- Frankfort Chava \& Nachmias David, (1996) Research Methods in Social Sciences, $5^{\text {th }}$ Edition, St Martin's Press, Inc, London

Nas, T., Price, A., \& Weber, C. (1986). A Policy-Oriented Theory of Corruption. The American Political Science Review, 80(1), 107-119. 10.2307/1957086

Newman, E. (2011). A Human Security Peace-Building Agenda. Third World Quarterly, 32(10), 1737-1756. Retrieved October 16, 2020, from http://www.jstor.org/stable/41341197

Olarinmoye, O. (2008). Politics Does Matter: The Nigerian State and Oil (Resource) Curse. Africa Development / Afrique Et DÃ Cveloppement, 33(3), 21-34. Retrieved August 29, 2020, from http://www.jstor.org/stable/24483994

Olzak, S. (1983). Contemporary Ethnic Mobilization. Annual Review of Sociology, 9, 355-374. Retrieved September 7, 2020, from http://www.jstor.org/stable/2946070

Palaniswamy, N., \& Krishnan, N. (2012). Local Politics, Political Institutions, and Public Resource Allocation. Economic Development and Cultural Change, 60(3), 449-473. doi:10.1086/664020

Paul, J and Danielle B, (2018) Conflict, Security and Development: An Introduction, London Routledge Taylor \& Francis Group 
Payne, G. \& Payne, J. (2004). Key informants. In Payne, G., \& Payne, J. Sage key Concepts: Key concepts in social research (pp. 135-138). London: SAGE Publications, Ltd doi: 10.4135/9781849209397

Pete, H, Shahin, M, Moran A \& Bruce P (2015) International Security Studies: Theory and Practice, London Routledge Taylor\& Francis Group

Peter Anassi, (2004). Corruption in Africa: The Kenyan Experience, A handbook for Civic Education on Corruption, Nairobi, Dialnet Communication Systems Limited-Kenya

Peters, P. (2013). Conflicts Over Land and Threats To Customary Tenure In Africa. African Affairs, 112(449), 543-562. Retrieved September 8, 2020, from http://www.jstor.org/stable/43817368

Poggie, J. (1972). Toward Quality Control in Key Informant Data. Human Organization, 31(1), 23-30. Retrieved September 5, 2020, from http://www.jstor.org/stable/44125113

Romborah Simiyu Robert, (2008),Militianisation of Resource Conflicts The Case of Land-Based Conflict in the Mount Elgon Region of Western Kenya ISS https://issafrica.org/research/monographs/militianisationof-resource-conflicts-the-case-of-land-based-conflict-in-the-mount-elgon-region-of-western-kenya

Ruhl, J. (2011). Political Corruption in Central America: Assessment and Explanation. Latin American Politics and Society, 53(1), 33-58. Retrieved August 16, 2020, from www.jstor.org/stable/41342299

Sandole, D.J.D, Byrne,S, Staroste-Sandole, I and Senehi, J. (Eds.). (2009). Handbook of Conflict Analysis and Resolution (6th ed.). New York, Routledge.

Saturnino M. Borras Jr., Ruth Hall, Ian Scoones, Ben White \& Wendy Wolford (2011) Towards a better understanding of global land grabbing: an editorial introduction, The Journal of Peasant Studies, 38:2, 209-216, DOI: 10.1080/03066150.2011.559005

Stake, Robert E. (2010) Qualitative Research: Studying How things Work, New York, The Guilford Press

Tavits, Margit. (2010) "Why Do People Engage in Corruption? The Case of Estonia." Social Forces 88, no. 3: 1257-279. Accessed October 10, 2020. http://www.jstor.org/stable/40645890.

Transparency International (2011): Corruption in the Land Sector, Working paper 04/2011. http://www.fao.org/3/am943e/am943e00.pdf retrieved on 13 October 2020

Tremblay, M. (1957). The Key Informant Technique: A Nonethnographic Application. American Anthropologist, 59(4), new series, 688-701. Retrieved September 5, 2020, from http://www.jstor.org/stable/666104

Unruh, J. (2010). Land Rights And Peacebuilding: Challenges And Responses For The International Community. International Journal of Peace Studies, 15(2), 89-125. Retrieved April 27, 2021, from http://www.jstor.org/stable/41853008

Wachira, K. Muluka,B, Wepundi, M., (2010) Mt. Elgon Conflict: A Rapid Assessment of the Underpinning Socioeconomic, Governance and Security Factors. DO - 10.13140/RG.2.1.3389.3605 retrieved on 9 September 2020

Wadström, A., Tetka, J., Chibamba, W., Yeakula, G., Brimah, J., \& Koroma, E. (2019). Understanding Land Corruption As A Basis For Prevention: Findings from Liberia, Sierra Leone and Zambia (pp. 09-12, Rep.). Transparency International. Retrieved April 26, 2021, from http://www.jstor.org/stable/resrep20593.8

Webel, C (2007).Towards a Philosophy and metapsychology of Peace in J. Galtung and W. Charles (Eds) Handbook of Peace and Conflict Studies, New York AND London, Routledge and Francis Group.

Wolff, Stefan. (2007). Ethnic Conflict: A Global Perspective. Oxford: Oxford University Press.

Working Group on Corruption and Security. (2014). (Rep.). Carnegie Endowment for International Peace. Retrieved August 18, 2020, from www.jstor.org/stable/resrep13073 
Reports

Impossible? Implementing the Ndungu Report. Africog Report 2006 https://africog.org/reports/mission_impossible_ndungu_report.pdf retrieved on 10 Sep 2020

Corruption and Land Governance in Kenya: https://tikenya.org/wp-content/uploads/2017/06/adili-issue-152corruption-and-land-governance-in-kenya.pdf accessed on 14 August 2020

Human Rights Watch Report (2008), All the Men Have Gone: War Crimes in Kenya's Mt Elgon Conflict: https://www.hrw.org/report/2008/07/27/all-men-have-gone/war-crimes-kenyas-mt-elgon-conflict

National Assembly Debates - 15 October 2019. Motion on Adoption of Report on Variation of Boundaries of Mt Elgon Forest Reserve. Retrieved on 8 Sep 20

National Assembly of Kenya (2019), Report of the Consideration of a Petition by Executive Regarding the variation of the boundaries of Mt Elgon Forest Reserve

Truth, Justice, and Reconciliation Commission, "Public Hearing Transcripts - Western - Mt. Elgon RTJRC23.05 (Kibuk Catholic Church)" (2011). I. Core TJRC Related Documents. 122. https://digitalcommons.law.seattleu.edu/tjrc-core/122

Mr. Cherotwei G Simotwo is MA Candidate at Kenyatta University, School of Security, Diplomacy and Peace Studies, Department of International Relations, Conflict and Strategic Studies Kenyatta University. He holds a Post Graduate Diploma in Strategic Studies from the University of Nairobi and Bachelor of Arts Degree from Egerton University

Dr. Xavier F. Ichani is the supervisor of the corresponding author's MA. Project. He holds a Doctor of Philosophy $(\mathrm{PhD})$ from Egerton University. He is currently a Lecturer, E- Learning \& Examination Coordinator in the School of Security, Diplomacy and Peace Studies of Kenyatta University 